\title{
MOOCs at the crossroads: \\ A literature review and reflection drawing upon discourse analysis
}

\author{
Laila Mohebi, PhD \\ Assistant Professor \\ College of Education \\ Zayed University \\ Marcelo F. Ponce, MD, PhD Student \\ City of Córdoba \\ Province of Córdoba \\ Argentina
}




\begin{abstract}
This study is a synthesis of 159 articles that were selected for their relevance to comprehend key aspects of the Massive Open Online Courses (MOOCs) phenomenon, from a discourse analysis perspective. Since 2011, MOOCs are expanding worldwide so that the number of subscribers outpointed 101 million at the end of 2018. This paper explores the question whether the MOOCs are the embodiment of the global one-world classroom or whether, instead, they represent a low-cost alternative tailored to a segment that doesn't have enough time or resources to attend a brick-and-mortar college. In addition, the review tackles the link between motivation and low completion rates. Finally, we discuss the need to devise better methods to assess the pedagogical value of MOOCs.
\end{abstract}

Keywords:

MOOCs

Distance education

Self-directed learning

Self-defined learning pathways

21 st century abilities 


\section{Introduction}

In 2012, a remarkable turning point occurred when Massive Open Online Courses (MOOCs) experience an explosion of offerings, worldwide. Since then, the development of the concept and the emergence of a range of diverse products in the MOOC market (Busta, 2019; Busteed, 2019; Millward, 2019; Moody, 2018) prompted educational researchers to strive to profoundly discern the nuances inside the complexity of the topic (Méndez García, 2013), the real value and true impact of different MOOC formats from a pedagogical perspective (Bali, 2014; Castaño-Garrido et al., 2015; Ebben \& Murphy, 2014; Guàrdia, Maina, \& Sangrà, 2013), and some related aspects, such as MOOC providers' evolving business models (Baturay, 2015; Feldman et al., 2018), their concerning and extremely high drop-out rates (Feng, Tang, \& Liu, 2019; Hone \& El Said, 2016; Kloft, Stiehler, Zheng, \& Pinkwart, 2014; Murray, 2019; Vitiello et al., 2018), and other facets of the phenomenon that we will try to tackle and explore deeply in this paper.

Education, Mark Twain once said, is the path from cocky ignorance to miserable uncertainty (Leckart, 2012). In this vein, we ask ourselves: Are MOOCs the embodiment of the global one-world classroom? What is the educational impact of this so-called "global oneworld classroom", if it really exists? Which is the relationship between MOOCs as a contemporary discourse and MOOCs as a tangible and measurable "learning-and-teaching" fact? Are really massive the "massive" open online courses? Are they really "open"?

Each letter of the MOOC acronym requires a profound reflection. For instance, the first letter, $\mathrm{M}$, is clearly an issue, in this regards. Where $\mathrm{M}$ stands in for the word massive, massive, the adjective, of course needs clarification and debate. Thus, in a postmodern world, while a plurality of readings converge and coalesce into MOOC as an acronym and significant, we propose to fathom into the MOOC meaning from an educational research perspective.

For all that, we draw upon discourse analysis techniques to deepen the social understanding of MOOC as a mode of delivering educational content and experiences thereby exploring the relevance of the format/s for pedagogical purposes, mostly in higher education.

\subsection{The discourse analysis approach and MOOCs}

Text and talk have both a crucial role in meaning production. According to Machin and Mayr (2012), discourse analysis techniques are useful tools in order to take "language and visual resources for evaluating social actors, and for signifying broader discourses, ideas and 
values that are not overtly articulated" (p. 57) (see also, Gee \& Handford, 2011; Schiffrin, Tannen, \& Hamilton, 2003; Van Dijk, 2016; Van Leeuwen, 2015).

As we perfectly know, education is positioned at the cornerstone of an evolving discourse system that outruns it. For example, with regard to curriculum design, doubtlessly this is a design for 'a future social subject', and by way of that envisioned subject, a design for a future society as well (see Kress, 1996, p. 16). So, being education formats specific forms of a set of discourses and semiotic systems, discourse analysis techniques are essential instruments whereby to uncover implicit meanings and any meaning production project, such as MOOCs, regardless of their complexity.

In dealing with MOOCs, discourse analysis stands out as a vehicle to put emphasis both on practices of production and on practices of reception (of meaning). In our view, the high dropout rate of MOOCs, in this sense, can be seen as a symptom of a mode of reception that disapproves certain aspects of the offerings, 'voting with the feet'. Even though unraveling the causes of the low completion rate in MOOCs deserves a profound analysis of the format/s and their specific content, the existence of a high drop-out rate brings to light that the original intention geared to offer "massive", "open", online courses was not achieved entirely, so far. Therefore, our aim is to offer a reflection of the meaning of the MOOC acronym by comparing the MOOC discourse with MOOC platforms' real-world evolution and trends.

All in all, from a discourse analysis and semiotic perspective (see Fairclough, 2003; Rogers et al., 2005, Rogers, 2017), the surge and expansion of MOOC offerings is a sign of the times as well, for the better and for the worse. In this context, the monomedial text as the only (or hegemonic) parameter of 'authority' in teaching and learning is debilitating in favor of transmediality (Méchoulan \& Carr, 2015; Nesselhauf \& Schleich, 2015). This is very relevant in view of Van Dijk's discourse analysis framework (2014) regarding the centrality of mental models in the link between reality, language, and interpretation of reality (see also MacLachlan $\&$ Reid, 1994). To clarify the idea, Van Dijk asserts that "mental models are multimodal. They represent the complex, embodied experience of events and situations, including visual, auditory, sensorimotor and emotional aspects of an experience" (p. 5). And we could add every educational experience as well. This is the reason why technology-enabled education offers the potential to create contents that are aligned with, or are in sync with, humans' mental models. Thus, multimodal discourse, media and mediation join up, and are mutually influenced (see also Blitvich \& Bou-Franch, 2018; Scolari, 2015).

\subsection{MOOCs as a discourse}


In an editorial published in Elsevier's Cell Systems in 2017, H. C. Mak underscores the relevance for the scientific community to harness online-, micro-, nano-, and blended learning formats inside the MOOC movement's offerings as a new stream of possibilities for strengthening the formation of biology researchers already working (or aspiring to work) in labs around the world (Mak, 2017). And Yousef, Chatti, Schroeder and Wosnitza (2014) point out that MOOCs mean a new technology-enhanced learning approach in higher education, as well. In this regard, one of the main themes of their reflection revolves around the notion of whether passive participants in MOOCs can (or should) be somehow active learners and the implications of this notion. Thus, in these previous two examples and in others, we can focus on MOOcs as a discourse. In our view, these positive statements are valuable to evince the type of "disruption" that MOOCs, according to some observers, are causing in the education landscape (see Adamopoulus, 2013; Head, 2014; Hoxby, 2014; Milheim, 2013; Mondal, 2017; Paldy, 2013; Perna et al., 2014; Signorelli \& Hovious, 2014; Stephens \& Jones, 2014). Further, in analyzing a large-scale corpus of text encompassing news media stories produced between January 2012 and December 2013, Bulfin, Pangrazio and Selwyn (2015) asserted that: a) MOOCs are clearly a disruptive and portentous development in the current higher education marketplace, b) in a certain way, MOOCs are reinforcing the established status quo in higher education — offering an alternative 'way in' to later study for 'proper' courses at 'proper', 'face to face' in brick-and-mortar universities, c) the MOOC discourse differ considerably to the ways in which MOOCs have tended to be imagined and discussed within specialist educational technology circles, and d) the relatively high levels of student dropout and disengagement from courses reveals the presence of a serious source of concern and a space of inconsistency between discourse (promise) and reality.

\subsection{The MOOCs market: some numbers}

Though the term MOOC was originally coined by George Siemens and Stephen Downes in the fall of 2008 in organizing a course on 'connectivism and connective knowledge' at the University of Manitoba, Canada (Gong, 2018), the MOOC market reached a significant size from 2012 on, when the number of MOOC-platform providers and MOOC offerings substantially took the ascending form they have today.

In 2018, more than 900 universities offered more than 11,400 MOOCs to 101 million subscribers (Shah, 2019). The global MOOC market is growing. It was valued at US\$3.61 
billion in 2018 and is expected to reach approximately US $\$ 25.33$ billion by 2025 , which means a composite annual growth rate (CAGR) of slightly above $32.09 \%$ between 2019 and 2025 (Zion Market Research, 2019). Additionally, according to public sources, among the four biggest MOOC platform providers, privately-owned Coursera generated about US $\$ 140$ million in 2018; $\underline{\text { Udacity }}$ earned US\$90 million for the year; $\underline{e d X}$ took in about US\$57 million for fiscal year 2017; and UK-based FutureLearn made about $£ 8.2$ million (see data from Schaffhauser, 2019). These data show that the business model of the leading MOOC platforms have changed since 2016, towards a format more attentive to revenue sources and revenue streams (ET, 2018).

\subsection{Research questions}

As part of a large research and development project, this study aims to deepen our understanding of the MOOC phenomenon. Thus, in what follows, we present the three research questions that are the backbone of this paper:

RQ1: Which are the main conclusions we can obtain so far from a published literature review about the educational debate on MOOCs?

RQ2: Which are the main features of the MOOC platform providers' websites we can currently observe as a discourse and as a sign of their business models and value proposition?

RQ3: What can we learn from a discourse analysis perspective applied to chat boxes' dialogues and asynchronous and synchronous discussion forum comments inside MOOC platform providers' websites?

\section{Materials and Methods}

The literature search was undertaken between April 25, 2019 and May 15, 2019 to identify peer-reviewed articles in English language, published between 2012 and 2019. Besides, a selected number of Spanish language papers were added when we deemed that they were of value for a better understanding of the current trends and directions inside the MOOC field of study. High-quality book chapters were also part of the accepted literature. Seventeen databases were included as sources of bibliographic data, i.e., Elsevier's Science Direct (https://www.sciencedirect.com), Oxford University Press (OUP) Journals Database (https://academic.oup.com), Cambridge University Press (CUP) Journals Database 
(http://www.cambridge.org/core), Wiley Online Library Database (https://www.onlinelibrary.wiley.com), ProQuest (https://www.proquest.com), Springer Journals Database (http://link.springer.com), Taylor \& Francis Journals (http://www.taylorfrancis.com), Sage Journals, Google Scholar, Google News, JSTOR (https://www.jstor.org), EBSCO (https://journals.ebsco.com), Elsevier's Social Science Research Network (SSRN) Database (http://www.ssrn.com), ResearchGate (https://www.researchgate.net), Academia.edu (www.academia.edu), Scopus Journals Database and Medline PubMed (https://www.ncbi.nlm.nih.gov).

Keywords included the following: "MOOCs", "MOOC platforms", "MOOC market", "MOOC business models", "MOOC drop-out rates", "e-learning", "online learning", "collaborative learning", "technology-enhanced learning", "lifelong learning", "discourse analysis", and "discourse analysis techniques". References of retrieved articles were assessed for relevant articles that our searches may have missed.

Selected MOOC-platform providers' websites, e.g., Coursera (www.coursera.org), edX (www.edx.org), Udemy (www.udemy.com), Udacity (www.udacity.com), Stanford University Online (https://online.stanford.edu/programs), UK's FutureLearn (https://www.futurelearn.com), OpenupEd (https://www.openuped.eu), New York City-based Flatiron School (https://flatironschool.com), France's Université Numérique (http://univnumerique.fr), Spain's MiríadaX (https://miriadax.net/home), Italy's EduOpen (wwws.learn.eduopen.org), Kadenze (www.kadenze.com), China's XuetangX (http://www.xuetangx.com/global), India's NPTEL (https://nptel.ac.in), India's Swayam (https://swayam.gov.in), and the Arab World's Edraak (www.edraak.org), were analyzed in order to evaluate MOOCs curricula design features, number and diversity of MOOCs offerings, course materials, prices, participating educational institutions, discussion forums, and rules for users, coupled with the quality of interfaces and user navigation pathways.

\section{Results}

This study is a synthesis of 159 articles mostly published between 2013 and 2019 that were selected for their relevance regarding one or more aspects of the complex MOOC phenomenon, from an educational research perspective. Because there seems to be very little that it is not possible to do online, online learning has become a strong option when deciding what format of education people will choose for learning. So, MOOCs are an excellent expression of these new trends in the digital era. However, as the evidence shows, there are 
still some barriers to overcome. For example, time management skills are central. Therefore, in order to be an effective learner one has to learn to be a good self-directed learner. Otherwise, the impact of the MOOC on proficiency, new competencies acquisition, and expertise will be very limited because the participant will drop out before completion (Abbakumov, Desmet, \& Van den Noortgate, 2018).

In the following subsection, we will focus on a review of the literature on MOOCs from 2013 to 2019.

\subsection{Review of the literature on MOOCs}

Last year, Zhu, Sari and Lee (2018) provided a systematic review of the recent empirical literature on MOOCs. They explored a set $(N=146)$ of empirical studies published between October 2014 and October 2016. Just as these papers applied either quantitative (45.9\%) or qualitative (18.5\%) approaches, in some cases, they used instead a mixed or combined analytic method (35.6\%). Even though the authors' aim was to increase the awareness of methodological issues and to make recommendations for future research, the set of dimensions explored by the empirical studies were diverse, including curriculum design, engagement, retention, massiveness and pedagogical impact, among others. As a drawback, they selected their journal articles from only 12 different journal titles, so as the word "systematic" in this 'systematic review' could be somehow put into question. Notwithstanding, Zhu, Sari, and Lee's paper was very useful for the present conceptual study, for their findings brought to light 24 distinct topics inside the MOOC field. In descending order, the 6 most cited topics were: a) motivation, b) retention, completion and drop-out, c) assessment, measurement and evaluation, d) instructional and MOOC design, e) learners' experiences, and f) satisfaction.

It is worth noting that Zhu, Sari, and Lee's intelligent paper is an extension of previous review studies on the MOOC field that encompassed different periods, i.e., 2008-2012 (Liyanagunawardena, Adams, \& Williams, 2013), 2008-2015 (Bozkurt, Akgün-Ŏzbek, \& Zawacki-Richter, 2017), 2009-2013 (Ebben \& Murphy, 2013), 2013-2015 (Veletsianos \& Shepherdson, 2016) and April 2014 to April 2016 (Deng \& Benckendorff, 2017).

MOOCs have been described as "free" courses, offered to a large number of learners at once, with open registration, and conducted via short video lectures, online assignments, interactive devices, multimodal language, and self-administered multiple-choice exams (Bass, 2014; Breslow et al., 2013; Chang \& Wei, 2016; Hood, Littlejohn, \& Milligan, 2015; McLaren, Donaldson, \& Smith, 2018; Méndez García, 2013; O’ Prey, 2013; Reeves \& Hedberg, 2014). 
From a discourse analysis perspective, both the M letter ("massive") and the first O letter ("open") require a debate. If "massive" refers to "a large number of learners at once", we can use comfortably the word "massive" to depict one of the supposed attributes of MOOCs. On the whole, it is clear that MOOCs, as it was just demonstrated, can reach a number of learners (audience) that a traditional in-classroom course is not capable of reaching. Hence, massiveness is a key concept to characterize any MOOC and any MOOC platform, albeit the world population is over 7 billion people. Nevertheless, this extensive literature review shows that "massiveness" and "openness" are concepts in flux. For instance, some authors interpret that the adjective "open" refers to "an open modality of registration" by which-contrary to what is common practice in elite universities-learners are not required to exhibit previous credentials or degrees to sign up for a post-secondary MOOC (see Farrow, de los Arcos, Pitt, \& Weller, 2015; Stewart, 2013). But being a subscriber (or a "registered user") is not synonymous with being an active learner. According to Class Central's founder and CEO D. Shah (2019), MOOC-platform providers attained an aggregated record number of 101 million "students" in 2018 (equivalent to $1.15 \%$ of the world population). To such an extent that the curve of the sector displaying the number of subscribers as a variable in relation to time forms the ascending part of a S-shaped curve or sigmoid curve. It is worthy of note here that some individuals are signed up for two or more different MOOC platforms simultaneously; therefore, the number of cumulative registered users of the sector is consequently higher than the number of individuals that once signed up for in a MOOC platform.

In coincidence with Cronin's standpoint "the qualifier open is variously used to describe resources (i.e., the artefacts themselves as well as access to and usage of them), learning and teaching practices, institutional practices, the use of educational technologies, and the values underlying educational endeavors" (Cronin, 2017, p. 16). Other authors point exclusively at the openness in the use of content or software along the learning process. Hence, the word open is polisemic, from a semantic perspective.

Sloep and Schuwer (2016) maintain that what the term "open" seems to carry as a significant is its reference to the removal of barriers to the access of education. But, in our view, access to a two- or three-week-long MOOC per year, however free it can be, is not a perfect equivalent to 'access to education'. Therefore, an "open" admission rule does not mean "open" in a sense of "free of charge". Precisely, many MOOC platforms are going through a transition towards a business model with more paid-only courses and less free-of-charge ones, with the purpose of propping up their financial sustainability (Belleflamme \& Jacqmin, 2015; ET, 2018; Jia, Song, Bai, \& Xu, 2017; Shah, 2016; Weller, 2015). 
As regards the motivation topic, the literature underscores that, as a factor, it is related to the high drop-out rate or low completion rate usually observed in MOOCs (Bakki et al., 2017; Barak, Watted, \& Haick, 2016; Castaño-Garrido et al., 2015; Huang \& Hew, 2016; MagenNagar, 2017; Wang \& Baker, 2015, 2018; Watted \& Barak, 2018; Ye \& Biswas, 2014). In an extensive study, Xu and Yang (2016) offered a classification of learners into 3 categories as a function of their type of motivation, namely: a) certification earning, b) video watching, and 3 ) course sampling. In the first group, individuals often have a high rate of completion because the participants' main purpose is to obtain a certification or, at least, a 'statement of achievement' from a prestigious educational institution. To the contrary, those inside the second group are not interested in obtaining a diploma, so they usually limit themselves to being video watchers, trying to leverage certain contents (they think) that are of value for them. And the third group consists of a segment of MOOC users that are exploring the platform's MOOC offerings and taking fractions or parts of courses only as a free sample.

While various studies on motivation and engagement outline the need to devise new measures to raise completion rates (see Greene, Oswald, \& Pomerantz, 2015; Li, Wang, \& Tan, 2018; Littlejohn et al., 2016; Zhou, 2016), a clear strategy to prevent drop-outs is not easy due to practical and contextual reasons (Kloft et al., 2014). However, Kim et al.'s experimental study (2017) from South Korea suggests that, on the basis of psychological reactance theory, MOOC designers and providers should have to restrict accessibility and limit repeatability of online courses. As they explain, learners should have to escape from infinite freedom. Also, in trying to understand the causal chain of the low completion rate in MOOCs, Eriksson, Adawi, and Stöhr (2017) identified 4 main factors that exert influence on the dropout rate, that is, a) the learner's perception of the course content, (b) the learner's perception of the course design, c) the learner's social situation and characteristics, and d) the learner's ability to find and manage time effectively. Further, Alraimi, Zo, and Ciganek (2015), in a research study focusing on factors that influence continuance in MOOCs underline that: a) perceived reputation, b) perceived openness, c) perceived usefulness and d) user satisfaction are the main elements that stand out. Doubtless, the perception of course design is linked with features of the pedagogical quality of the course. Margaryan, Blanco, and Littlejohn (2015) generated valuable evidence when they carried out an assessment of instructional design quality of 76 randomly selected MOOCs. According to the authors, the majority of evaluated MOOCs scored poorly on most instructional design principles but most MOOCs scored highly on organization and presentation of course material. As a consequence, the results contribute to conclude that although most MOOCs are well-packaged, their instructional design is low, so 
there is room for improvement to stimulate student retention (see also Al-Rahmi et al., 2019; Brooker, Corrin, de Barba, Lodge, \& Kennedy, 2018; Xiong, Li, Kornhaber, Suen, Pursel, \& Goins, 2015).

\subsection{An overview of selected MOOC platform providers' websites}

Founded on June 16, 2015, Kadenze Inc. is a for-profit MOOC platform provider. As of May 2019, it offers a total of 217 MOOCs-mostly about art and music-, among which are 28 credit-eligible courses. Credit eligible courses are courses that can be taken for 'a transferable college credit' from the offering institution. For example, the Contemporary Museum Education course for beginners, in association with the New York City-based Pratt Institute, is a 5-session (10 hours of work per session) course that is "free" but is credit-eligible in exchange for US\$ 300. Also, once completed, the platform awards a 'certificate of achievement' provided that the user obtains a grade of $65 \%$ or higher and is a premium member, in exchange for US\$20 per month. Only premium members can view certain videos, submit assignments, enjoy discounts in course materials such as software, and receive grades and feedback from instructors. This case shows that the value proposition and business model of some MOOC platforms combine the benefits of free registration, short length, and visual technologies with specific paid-only accessibility rules with respect to credits and certificates of achievement, that a segment of participants regards desirable, but others not. This is known as a tier-based membership model or a multi-tier pricing scheme (see Gullhav \& Nygreen, 2016). Furthermore, Kadenze has two types of courses, i.e., scheduled and adaptive courses. A schedule course follows a set calendar with start and end dates. On the contrary, in adaptive courses, each participant progresses at his/her own pace.

UK's FutureLearn, a non-for-profit, was founded in 2013. It has 82 educational partners and offers 303 courses organized in 13 different categories, such as Literature, Nature \& Environment, and Politics \& the Modern World, among others. Most of the courses are six to ten weeks long and are intended to be at undergraduate level. Like Kadenze, FutureLearn offers a free membership. But, besides, it provides an 'upgrade membership', by which participants, if they are eligible, have an exclusive right to receive a 'certificate of achievement'. Additionally, it gives an additional option to take an 'unlimited membership' in exchange for US\$ 199 per year to get access to all the courses and, once completed, their respective certificates of achievement. In addition, courses are clustered into programs. For example, the Digital Media Analytics program is made up of 7 courses with a total duration of 
15 weeks. Those who complete the 7-course program receive three credits for the Purdue University Graduate School's Masters of Professional Communication degree program.

Spain's MiríadaX offers 473 courses with 87 educational partners. One of the courses is The Art of Developing Entrepreneurial Leaders (2nd. edition) in association with Universidad del Rosario, with a duration of 4 weeks (24 estimated hours of self-study time) at a price of $€ 40$.

Coursera, the largest MOOC provider by the number of registered users, offers 1 week free of charge in all courses, as a sample, but the registrant has to pay a monthly fee at the end of the first week to stay as an active student. One of the conditions of the initial registration is to give the credit card number.

Further, Udacity offers a set of free courses, e.g., Artificial Intelligence for Robotics in collaboration with Georgia Tech University, which is composed of 24 lessons. The courses are organized into programs, such as Artificial Intelligence, Data Science, Programming \& Development, Autonomous Systems, and Business. This MOOC platform stands out because it shows efforts to connect participants with an enrollment advisor and career coaching sessions to evaluate career and new job opportunities. For space reasons, a detailed description and critique of MOOC platforms' characteristics will be published in an upcoming paper.

\subsection{Discourse analysis of the MOOC industry narrative}

To start with, we want to focus on certain statements such as the following: "(...) While by definition, the MOOCs are free and open-to-all, the MOOC platforms sell value-added MOOC services for profit, and it is a common model in Internet services called the freemium strategy" (Jia, Song, Bai, \& Xu, 2017, p. 2). In this respect, Kumar (2014) explains that a 'freemium business model' is often used by some digital businesses and smart-phone application developers to give users free basic features of a digital product and access to premium functionality for a subscription fee. Whereas the freemium business model is being adopted by for-profit MOOC platforms-such as Coursera and Udacity-most firms suffer from too few premium subscribers, which challenges their profitability (Koch, 2017). But the main point here is conceptual, not financial. Will MOOC-platform providers be able to deliver their original promise to offer an "open-to-all" online education when the best courses have a price, and the price barrier is, for some, a barrier to access? (see also Bernhard, Bittel, Van Der Vlies, Bettoni, \& Roth, 2013; Burd, Smith, \& Reisman, 2015). 
"The shimmery hope is that free courses can bring the best education in the world to the most remote corners of the planet, help people in their careers, and expand intellectual and personal networks", said Laura Pappano in The New York Times in Nov. 2, 2012 (Pappano, 2012). However, some barriers persist before this idealistic vision. In an interesting article published in Science, Kizilcec, Saltarelli, Reich, and Cohen (2017) stressed the existence of a global achievement gap in MOOC-enabled learning. For example, using data from 68 MOOCs offered by Harvard and MIT in the 2012-2014 academic years, Hansen and Reich (2015) found that course unique participants $(N=1,028,269)$ on the edX platform from the US tended to live in more affluent and better-educated neighborhoods than the average US resident. Among those who do registered for courses, students with greater socioeconomic resources were more likely to earn a certificate. Further, these differences in MOOC access, retention and completion rates were larger for adolescents and young adults, the traditional ages where people find on-ramps into STEM coursework and careers. So, Hansen and Reich's findings raised concerns that MOOCs and similar approaches to online learning can exacerbate rather than reduce disparities in educational outcomes related to socioeconomic status. Additionally, a recent study confirmed that the vast majority of MOOC learners never return after their first year, the growth in MOOC participation has been concentrated almost entirely in the world's most affluent countries, and the bane of MOOCs, i.e., low completion rates, has not improved over 6 years (Reich \& Ruipérez Valiente, 2019). To see more empirical evidence on inequality of acces to MOOCs, see also Adham and Lundqvist (2015), Christensen et al., 2014, Gameel and Wilkins (2019), Karr (2014), Rohs and Ganz (2015), Selingo (2014a) and van de Oudeweetering and Agirdag (2018).

\subsection{Discourse analysis of conversations at MOOC platforms on MOOCs}

A MOOC user, Aung K., says in a chat conversation at UK's FutureLearn:

\footnotetext{
"I like to learn courses a lot, but I can't find any free time for that. Sometimes, I just forgot the course, may be I am not so serious on learning as I have lack of motivation on lea(r)ning online. But I hopefully this short course can (s)how me the way to learn online courses".
}

As we can see, from a discourse analysis perspective, this statement is very rich as it highlights what a segment of current learners are facing up with respect to the topic of the 'scarcity of time' and certain time management deficits, in the global contemporary society. 
This was observed when trying to accomplish a specific schedule, even in an online 2-week short course with a workload of only 3 hours per week untitled 'Get Started with Online Learning', by the Open University. Further, this comment adds a perspective on the high dropout rate of the MOOCs, in general, which is, in a certain way, linked with "the lack of motivation".

Regarding the nexus between online life and online education, Laura H., a lead educator at FutureLearn affirms: "In 2014, 38 million adults (76\%) in the UK accessed the internet every day. This is 21 million more than in 2006, when directly comparable records began". This jump in the numbers in only 8 years outlines the current scenario in relation to online activities, at least in a developed country the size of UK.

Also, Tetiana Z. adds: "Online education is a good opportunity to find and choose what I really want and need" putting into her own words what scholars regard as self-defined learning pathways, which is a notable characteristic of MOOCs. In another public chat box, Georgina O. says: "The line and boundary between formal and informal learning has been blurred". Additionally, on the online learning process, Irina K. points out that "there is no any contact face to face and it is probably the weakest side of such communication".

With regard to feedbacks and the interaction with tutors, Sandra C. says:

“(...) When we are studying, we do need to be able to hear the negatives as well as the positives, this is the only way we can learn and progress. I think I am reasonably good at accepting constructive criticism, although I must admit I am more receptive if I don't know I am receiving it".

One of the distinguishing features of MOOCs' discussion forums is that peer-to-peer contact enriches the learning experience and forms a network of trust, cross-cultural sharing, motivation and collaborative problem-solving (Damary, Markova, Pryadilina, 2017; Kuong, 2015; Sharif \& Magrill, 2015) with a positive impact on retention rates, and knowledge acquisition (Swinnerton, Hotchkiss, \& Morris, 2017).

Jones, Chik, and Hafner, (2015) in Discourse and digital practices: Doing discourse analysis in the digital age maintain that "in some cases, the tools that have been developed for face-to-face conversation and writing in print media can be easily adapted to analyze online conversations and texts" (p. 8). Even though the value of the analysis of discussion forum posts has certain limits due to the fact that online participants are registered users of the MOOC in question, some statements are useful to bring to light the style and relationship between learners' expectations and the new learning digital platform content and instructional design 
(see also, Anbalagan, Kumar, \& Bijlani, 2015; Bernad-Mechó, 2015). All in all, the study of digitally-mediated communication in some ways forces us to rethink our very definitions of terms such as text, context, interaction, satisfaction, and power (Gardner \& Brooks, 2018; Gee \& Handford, 2011; Woods, 2006).

\section{Discussion}

A process of massification of education does not necessarily means education of low quality for all. Rather, the ongoing evolution of digital media is creating a new condition of possibility whereby to expand the number of individuals, of all ages, that can receive a highquality education experience. Naturally, the growing number of registered users in MOOC platforms documented since the successful experiment carried out by Stanford University faculty members Sebastian Thrun and Peter Norvig in the fall of 2011 is revealing a power shift from a traditional mode of provision of education inside the walls of a brick-and-mortar university towards an experimental form of learning that can be accessible to whoever has an internet access (Brahimi \& Sarirete, 2015; Brazas \& Oullette, 2013; Schophuizen, Kreijns, Stoyanov, \& Kalz, 2018; Wrigley, Mosely, \& Tomitsh, 2018).

However, the whole picture is more complex. As Selingo (2014b) clearly stated, "MOOCs put students in control. Students can do as much or as little as they want at any time, one reason that many never complete the courses. Roughly one in 10 finishes".

In this vein, Jordan's study (2014), in assessing a sample $(N=279)$ of MOOCs from different platforms, corroborated that the average MOOC course was found to enroll around 43,000 students, of whom only $6.5 \%$ completed the course. This means a dropout rate of 93.5\%. Moreover, her findings bore out that completion rates were consistent across time, university rank, and total enrollment, but were negatively correlated with course length, that is, the longer the course, the smaller the completion rate. In another study, on the edX platform, there were 43,196 students that earned the certificates of completion among a total of 841,687 registrants, hence, the completion rate was barely $5.1 \%$ (Ho, Reich, Nesterko, Seaton, Mullaney, Waldo, \& Chuang, 2014). Owing to the fact that this extremely low completion rate was also confirmed by other authors (e.g., Breslow et al., 2013; Koller, Ng, \& Chen, 2013; Li $\&$ Baker, 2018), this is still a cause of profound concern in the MOOC field of study (Meinert, Alturkistani, Brindley, Carter, Wells, \& Car, 2018).

Still, Henderikx, Kreijens, and Kalz (2017), from the Netherlands, offer an alternative view. They contend that a certificate-centric or a completion-centric form of evaluation is not the 
most appropriate option to obtain a conclusion on the pedagogical impact of MOOCs. They maintain that "framing success from a certificate- and completion-centric view will nurture a false understanding of success and dropout in MOOCs, which may subsequently lead to unnecessary interventions and unjustified negative reviews" (p. 2). The core of their thesis revolves around the following concept: Students entering education might have intentions other than receiving an end qualification. Therefore, they propose that success measurements of MOOCs should be interpreted with MOOC-takers' intent in mind, that is, with a more learner-centered approach.

The best way to measure the proficiency of students that completed a MOOC or a set of MOOCs is in discussion (Bryson, 2017; Steffens, 2015; Terras \& Ramsay, 2015; Zhong, Zhang, Li, \& Liu, 2016). For example, Abbakumov, Desmet and Van der Noortgate (2018), using a modification of the Rasch model, found that the measurement of proficiency is complex and relatively inaccurate because: a) assessments are dynamic and, in MOOCs, new content can be added, removed or replaced by a course designer or provider at any time; b) students are allowed to make several attempts within one assessment; and c) assessments include an insufficient number of items for accurate individual-level conclusions. And in coincidence with these authors, other scholars affirm that, given the open nature of MOOCs, better tools are still needed to evaluate the pedagogical impact of MOOCs properly (Cabrera \& Fernández-Ferrer, 2017; Chapman, Goodman, Jawitz, \& Deacon, 2016; DeBoer, Ho, Stump, \& Brelow, 2014; Del Peral Pérez, 2019; Duart, Roig-Vila, Mengual-Andrés, \& Maseda Durán, 2017; Jung \& Lee, 2018; Kesim \& Altinpulluk, 2015; López-Meneses, Bernal, Leiva, \& Martín, 2018).

Moreover, some authors have identified different subgroups among MOOC-takers with different profiles in relation to engagement, completion rates, accomplishment, and learning outcomes. For example, Li and Baker (2018) found heterogeneity in behavioral patterns among learners that is expression of different levels of engagement, and different reasons why participants decide to engage (see also Walji, Deacon, Small, \& Czerniewicz, 2016; Williams, Stafford, Corliss, \& Reilly, 2018; Zhang, Cesar Bonafini, Lockee, Jablokow, \& Hu, 2019). In sum, they conclude that in MOOCs the existence of self-defined learning pathways generates the need to apply different measures to discern the way learners are taking advantage of the content of the courses (see also Petronzi \& Hadi, 2016; Reilly, Williams, Stafford, Corliss, Walkow, \& Kidwell, 2016; Shapiro, Lee, C. H., Wyman Roth, Li, Çetinkaya-Rundel, \& Canelas, 2017; Tseng, Tsao, Yu, Chan, \& Lai, 2016). 
Advocates of MOOCs-based learning proclaim that MOOCs have the potential to "equalize" the playing field by eliminating barriers such as tuition costs, age, prerequisites, time constraints, and selective admission policies (Ebner, 2016). But, at the same time, critics have expressed fears because they envisage that the advent and proliferation of MOOCs in higher education will accelerate a deterioration of the University system by creating a two-tier education, i.e., a first-class, high-cost offering for the privileged and the few, and a secondclass, low-cost, internet-delivered offering for the underprivileged (Schrag, 2014; Young, 2018).

The distance between massive enrollment and low completion rates has convinced many to put into question the pedagogical value of MOOCs and their capacity to transform higher education for the better. This is the reason why the topic still elicits ambiguity among educators (Schophuizen et al., 2018). Because entirely online learning has advantages and disadvantages (Fernández-Díaz, Rodríguez-Hoyos, \& Calvo Salvador, 2017; Vázquez Cano \& López Meneses, 2014), some scholars, instead, are encouraging the adoption of a hybrid or blended format of teaching and learning (Bruff, Fisher, McEwen, \& Smith, 2013; Emanuel \& Lamb, 2015; Fidalgo-Blanco, Sein-Echaluce, \& García-Peñalvo, 2016; García-Peñalvo, FidalgoBlanco, \& Sein-Echaluce, 2018; Nortvig \& Christiansen, 2017; Slomanson, 2014; Trentin \& Bocconi, 2014).

Finally, it is important to add that despite the unresolved debate regarding the role and real impact of MOOCs on higher education's future, MOOCs are clearly a valuable tool as an alternative form of delivery of education in conformity with lifelong learning requirements in the 21st century society (Quendler \& Lamb, 2015; Volles, 2014).

\section{Conclusions}

Since 2012, MOOCs exhibit a great potential to satisfy the needs of a growing segment of the educational market, specially, among those that have time constraints or insufficient resources to comply with the prerequisites of a conventional higher education program. This innovation is suitable for learners that have persistence, a high degree of self-motivation, are in search of a new employment, and are able to develop a self-defined learning path. Yet, according to the evidence, it remains to be seen whether this form of delivery of education is an appropriate way of democratizing education and making an open-to-all learning a reality, regardless of language proficiency, place of residence, capacity to engage, and cultural competencies. 


\section{References}

Abbakumov, D., Desmet, P., \& Van den Noortgate, W. (2018). Measuring student's proficiency in MOOCs: Multiple attempts extensions for the Rasch model. Heliyon, 4, e01003 doi:10.1016/j.heliyon.2018.e01003.

Adamopoulos, P. (2013). What makes a great MOOC? An interdisciplinary analysis of student retention in online courses. In Thirty Fourth International Conference on Information Systems (pp. 1-21), Milan, Italy.

Adham, R. S., \& Lundqvist, K. O. (2015) MOOCs as a method of distance education in the Arab World-A review paper. European Journal of Open, Distance and e-Learning, $18(1), 123-139$.

Al-Rahmi, W., Aldraiweesh, A., Yahaya, N., Kamin, Y. B., \& Zeki, A. M. (2019). Massive open online courses (MOOCs): Data on higher education. Data in Brief, 22, 118-125.

Alraimi, K. M., Zo, H., \& Ciganek, A. P. (2015). Understanding the MOOC continuance: The role of openness and reputation. Computers \& Education, 80, 28-38.

Anbalagan, R., Kumar, A., \& Bijlani, K. (2015). Footprint model for discussion forums in MOOC. Procedia Computer Science, 58, 530-537.

Bakki, A., Oubahssi, L., Cherkaoui, C., \& George, S. (2017). Motivation and engagement in MOOCs: How to increase learning motivation by adapting pedagogical scenarios? HAL Archives-Ouvertes, France. Retrieved May 8, 2019 from https://hal.archivesouvertes.fr/hal-01646708/document

Bali, M. (2014). MOOC pedagogy: Gleaning good practice from existing MOOCs. MERLOT Journal of Online Learning and Teaching, 10(1), 44-56.

Barak, M., Watted, A., \& Haick, H. (2016). Motivation to learn in massive open online courses: Examining aspects of language and social engagement. Computers \& Education, 94, 49-60.

Bass, S. A. (2014). Simple solutions to complex problems-MOOCs as a panacea? The Journal of General Education, 63(4), 256-268.

Baturay, M. H. (2015). An overview of the world of MOOCs. Procedia - Social and Behavioral Sciences, 174, 427-433.

Belleflamme, P., \& Jacqmin, J. (2015). An economic appraisal of MOOC platforms: Business models and impacts on higher education. CESifo Economic Studies, 1-22, doi:10.1093/cesifo/ifv016. 
Bernad-Mechó, E. (2015): A multimodal discouse analysis of linking metadiscoursive elements in two opencourseware lectures (MOOCs). Procedia - Social and Behavioral Sciences, 212, 61-66.

Bernhard, W., Bittel, N., Van Der Vlies, S., Bettoni, M., \& Roth, N. (2013). The MOOCs business model. Procedia - Social and Behavioral Sciences, 106, 2931-2937.

Blitvich, P. G., \& Bou-Franch, P. (2018). Introduction to analyzing digital discourse. In P. Bou-Franch \& Garcés-Conejos Blitvich, P. Analyzing digital discourse: New insights and future directions (pp. 4-22). Palgrave Macmillan.

Bozkurt, A., Akgun-Ozbek, E., Zawacki-Richter, O. (2017). Trends and patterns in massive open online courses: Review and content analysis of research in MOOCs (2008-2015). International Review Research on Open and Distributed Learning, 18(5), 118-147.

Brahimi, T., \& Sarirate, A. (2015). Learning outside the classroom through MOOCs. Computers in Human Behavior, 51, Part B, 604-609.

Brazas, M. D., \& Oullette, B. F. F. (2013). Navigating the changing learning lanscape: Perspective from Bioinformatics.ca. Briefings in Bioinformatics, 14(5), 556-562.

Breslow, L., Pritchard, D. E., DeBoer, J., Stump, G. S., Ho, A. D., \& Seaton, D. T. (2013). Studying learning in the worldwide classroom: Research into edX's first MOOC. Research \& Practice in Assessment, 8, 13-25.

Brooker, A., Corrin, L., de Barba, P., Lodge, J., \& Kennedy, G. (2018). A tale of two MOOCs: How student motivation and participation predict learning outcomes in different MOOCs. Australasian Journal of Educational Technology, 34(1), 73-87.

Bruff, D. O., Fisher, D. H., McEwen, K. E., \& Smith, B. E. (2013). Wrapping a MOOC: Student perceptions of an experiment in blended learning. MERLOT Journal of Online Learning and Teaching, 9(2), 187-199.

Bryson, D. (2017). Can MOOCs meet your learning needs? Journal of Visual Communication in Medicine, 40(4), 170-172.

Bulfin, S., Pangrazio, L., \& Selwyn, N. (2014). Making MOOCs: The construction of a new digital higher education within news media discourse. The International Review of Research in Open and Distance Learning, 15(5), https://doi.org/10.19173/irrodl.v15i5.1856

Burd, E. L., Smith, S. P., \& Reisman, S. (2015). Exploring business models for MOOCs in higher education. Innovative Higher Education, 40(1), 37-49.

Busta, H. (2019, April 26). After raising \$103M, MOOC-provider Coursera eyes global expansion. Education Dive, Retrieved May 3, 2019 from 
https://www.educationdive.com/news/after-raising-103m-mooc-provider-courseraeyes-global-expansion/553532/

Busteed, B. (2019, Feb. 26). Why Goodwill (Not Udacity, edX or Coursera) may be the world's biggest MOOC. Forbes, Retrieved May 4, 2019 from https://www.forbes.com/sites/brandonbusteed/2019/02/26/why-goodwill-not-udacityedx-or-coursera-may-be-the-worlds-biggest-mooc/\#4fea9c929048

Cabrera, N., \& Fernández-Ferrer, M. (2017). Examining MOOCs: A comparative study among educational technology experts in traditional and open universities. International Review of Research in Open and Distributed Learning, 18(2), 47-67.

Castaño-Garrido, C., Maiz-Olazabalaga, I., \& Garay-Ruiz, U. (2015). Diseño, motivación y rendimiento en un curso MOOC cooperativo. Comunicar, 44(22), 19-26.

Chang, J.-W., \& Wei, H. Y. (2016). Exploring engaging gamification mechanics in massive open online courses. Journal of Educational Technology \& Society, 19(2), 177-203.

Chapman, S. A., Goodman, S., Jawitz, J., \& Deacon, A. (2016). A strategy for monitoring and evaluating massive open online courses. Evaluation and Program Planning, 57, 55-63.

Christensen, G., Steinmetz, A., Alcorn, B., Bennett, A., Woods, D., \& Emanuel, E. J. (2014). The MOOC phenomenon: Who takes open online courses and why? University of Pennsylvania Working Paper,

file://C:/Users/m/Downloads/SSRN-id2350964.pdf

Cronin, C. (2017). Openness and praxis: Exploring the use of open educational practices in higher education. International Review of Research in Open and Distributed Learning, 18(5), 15-34.

Damary, R., Markova, T., Pryadilina, N. (2017). Key challenges of on-line education in multicultural context. Procedia - Social and Behavioral Sciences, 237, 83-89.

DeBoer, J., Ho, A. D., Stump, G. S., \& Brelow, L. (2014). Changing "course": Reconceptualizaing educational variables for massive open online courses. Educational Researcher, 43(2), 74-84.

Del Peral Pérez, J. J. (2019). Patrones temporales de participación en MOOC. Estudio de un MOOC de lenguas [Temporal patterns of MOOC Participation. Case study of a language MOOC]. RIED Revista Iberoamericana de Educación a Distancia, 22(2), http://dx.doi.org/10.5944/ried.22.2.23109.

Deng, R., \& Benckendorff, P. (2017). A contemporary review of research methods adopted to understand students' and instructors'use of massive open online courses (MOOCs). International Journal of Information and Education Technology, 7(8), 601-607. 
Duart, J. M., Roig-Vila, R., Mengual-Andrés, S., \& Maseda Durán, M.-A. (2017). La calidad pedagógica de los MOOC a partir de la revisión sistemática de las publicaciones JCR y Scopus (2013-2015). Revista Española de Pedagogía, 75(266), 29-46.

Ebben, M., \& Murphy, J. S. (2014). Unpacking MOOC scholarly discourse: A review of nascent MOOC scholarship. Learning, Media and Technology, 39(3), 328-345.

Ebner, N. (2016). Negotiation and conflict resolution in the age of the MOOC. Negotiation Journal, 32(3), 231-260.

Emanuel, J. P., \& Lamb, A. (2015). Open, online, and blended: Transactional interactions with MOOC content by learners in three different course formats. Harvard University Graduate School of Education Working Paper, https://papers.ssrn.com/sol3/papers.cfm?abstract_id=2666657

Eriksson, T., Adawi, T., \& Stöhr, C. (2017). "Time is the bottleneck": A qualitative study exploring why learners drop out of MOOCs. Journal of Computing in Higher Education, 29(1), 133-146.

ET. (2018, Sept. 28). MOCCs: Paradise lost? Education Technology, Retrieved May 9, 2019, from https://edtechnology.co.uk/Article/moocs-paradise-lost

Fairclough, N. (2003). Analysing discourse: Textual analysis for social research. London, Routledge.

Farrow, R., de los Arcos, B., Pitt, R., \& Weller, M. (2015). Who are the open learners? A comparative study profiling non-formal users of open educational resources. European Journal of Open, Distance and e-Learning, 18(2), 50-74.

Feldman, A., Carson, B., Adams, S., Robehmed, N., Kauflin J., Tindera, M., ... Kreznar, C. (2018, October 15). The next billion-dollar startups 2018. Forbes, Retrieved May 3, 2019 from https://www.forbes.com/next-billion-dollar-startups/\#6c7b208c4441

Feng, W., Tang, J, \& Liu, T. X. (2019). Understanding dropouts in MOOCs. PBC School of Finance of Tsinghua University and Association for the Advancement of Artificial Intelligence. Retrieved May 6, 2019 from:

http://keg.cs.tsinghua.edu.cn/jietang/publications/AAAI19-Feng-dropout-moocs.pdf

Fernández-Díaz, E., Rodríguez-Hoyos, C., \& Calvo Salvador, A. (2017). The pedagogic architecture of MOOC: A research project on educational courses in Spanish. International Review of Research on Open and Distributed Learning, 18(6), 18-35.

Fidalgo-Blanco, Á., Sein-Echaluce, M. L., \& García-Peñalvo, F. J. (2016). From masive access to cooperation: Lessons learned and proven results of a hybrid xMOOC/cMOOC 
pedagogical approach to MOOCs. International Journal of Educational Technology in Higher Education, 13(24), 1-13.

Gameel, B. G., \& Wilkins, K., G. (2019). When it comes to MOOCs, where you are from makes a difference. Computers \& Education, 136, 49-60.

García-Peñalvo, F. J., Fidalgo-Blanco, Á., \& Sein-Echaluce, M. L. (2018). An adaptive hybrid MOOC model: Disrupting the MOOC concept in higher education. Telematics and Informatics, 35(4), 1018-1030.

Gardner, J., \& Brooks, C. (2018). Student success prediction in MOOCs. User Modeling and User-Adapted Interaction, 28(2), 127-203.

Gee, J. P., \& Handford, M. (2011). The Routledge Handbook of Discourse Analysis. Routledge, Taylor \& Francis.

Gong, Z. (2018). The development of medical MOOCs in China: Current situation and challenges. Medical Education Online, 23, https://doi.org/10.1080/10872981.2018.1527624

Greene, J. A., Oswald, C. A., \& Pomerantz, J. (2015). Predictors of retention and achievement in massive open online course. American Educational Research Journal, 52(5), 925 955.

Guàrdia, L., Maina, M., \& Sangrà, A. (2013). MOOC design principles. A pedagogical approach from the learner's perspective. eLearning Papers, 33, 1-6.

Gullhav, A. N., \& Nygreen, B. (2016). A branch and price approach for deployment of multitier software services in clouds. Computers \& Operations Research, 75, 12-27.

Hansen, J. D., \& Reich, J. (2015). Democratizing education? Examining access and usage patterns in massive open online couses. Science, 350(6265), 1245-1248.

Head, K. (2014). Are MOOCs the future of general education? The Journal of General Education, 63(4), 244-255.

Henderikx, M. A., Kreijns, K., \& Kalz, M. refining success and dropout in massive open online courses based on the intention-behavior gap. Distance Education, doi:10.1080/01587919.2017.1369006.

Ho, A. D., Reich, J., Nesterko, S., Seaton, D. T., Mullaney, T., Waldo, J., \& Chuang, I. (2014). HarvardX and MITx: The first year of open online courses. HarvardX and MITx Working Paper $\mathrm{N}^{\mathrm{o}} 1$.

file:///C:/Users/m/Downloads/SSRN-id2381263.pdf

Hone, K. S., \& El Said, G. R. (2016). Exploring the factors affecting MOOC retention: A survey study. Computers \& Education, 98, 157-168. 
Hood, N., Littlejohn, A., \& Milligan, C. (2015). Context Counts: How learners' contexts influence learning in a MOOC. Computers \& Education doi: 10.1016/j.compedu.2015.10.019.

Hoxby, C. M. (2014). The economics of online postsecondary education: MOOCs, non selective education, and highly selective education. The American Economic Review, 104(5), 528-533.

Huang, B., \& Hew, K. F. (2016). Measuring learners' motivation level in massive open online courses. International Journal of Information and Education Technology, 6(10), 759764.

Jia, Y., Song, Z., Bai, X., \& Xu, W. (2017). Towards economic models for MOOC pricing strategy design. Institute of Interdisciplinary Information Sciences, Tsinghua University and Faculty of Education, University of Hong Kong. https://arxiv.org/pdf/1701.03998.pdf

Jones, R. H., Chik, A., \& Hafner, C. A. (2015). Discourse analysis and digital practices. In Discourse and digital practices: Doing discourse analysis in the digital age (pp. 1-17). London, Routledge (Chapter 1).

Jordan, K. (2014). Initial trends in enrolment and completion of massive open online courses. The International Review of Research in Open and Distribute Learning, 15(1), 133-160.

Jung, Y., \& Lee, J. (2018). Learning engagement and persistence in massive open online courses (MOOCs). Computers \& Education, 122, 9-22.

Karr, J. (2014, Oct. 30). A history of MOOCs, open online courses. The New York Times, Retrieved May 10, 2019 from https://bits.blogs.nytimes.com/2014/10/30/a-history-of-moocs-open-online-courses

Kesim, M., \& Altinpulluk, H. (2015). A theoretical analysis of MOOCs types from a perspective of learning theories. Procedia - Social and Behavioral Sciences, 186, 1519.

Kim, T., Yang, M, Bae, J., Min, B., Lee, I., \& Kim. J. (2017). Escape from infinite freedom: Effects of constraining user freedom on the prevention of dropout in an online learning context. Computers in Human Behavior, 66, 217-231.

Kizilcec, R. F., Saltarelli, A. J., Reich, J., \& Cohen, G. L. (2017). Closing global achievement gaps in MOOCs. Science, 355(6322), 251-252.

Kloft, M., Stiehler, F., Zheng, Z, \& Pinkwart, N. (2014). Predicting MOOC dropout over weeks using machine learning methods. In Proceedings of the 2014 Conference on 
Empirical Methods in Natural Language Processing (EMNLP) (pp. 60-65). Doha, Qatar.

Koch, O. F. (2017). The effect of free sampling strategies on freemium conversion rates. Electronic Markets, 27(1), 67-76.

Koller, D., Ng, A., \& Chen, Z. (2013). Retention and intention in massive open online courses: In depth. Educause Review, Retrieved May 11, 2019 from https://er.educause.edu/articles/2013/6/retention-and-intention-in-massive-openonline-courses-in-depth

Kress, G. (1996). Representational resources and the production of subjectivity: Questions for the theoretical development of critical discourse analysis in a multicultural society. In C. Caldas-Coulthard \& M. Coulthard (Eds) Texts and practices: Readings in critical discourse analysis (pp. 15-31). London and New York, Routledge (Chapter 2).

Kumar, V. (2015). Making freemium work. Harvard Business Review, 92(5), 27-29.

Kuong, H. C. (2015). Enhancing online learning experience: From learners' perspective. Procedia - Social and Behavioral Sciences, 191, 1002-1005.

Leckart, S. (2012, Mar. 20). The Stanford education experiment could change higher learning forever. Wired, Retrieved May 5, 2019 from https://www.wired.com/2012/03/ff_aiclass

Li, B., Wang, X., \& Tan, S. C. (2018). What makes MOOC users persist in completing MOOCs? A perspective from network externalities and human factors. Computers in Human Behavior, 85, 385-395.

Li, Q., \& Baker, R. (2018). The different relationships between engagement and outcomes across participant subgroups in massive open online courses. Computers \& Education, $127,41-65$.

Littlejohn, A., Hood, N., Milligan, C., \& Mustain, P. (2016). Learning in MOOCs: Motivations and self-regulated learning in MOOCs. The Internet and Higher Education, 29, 4048.

Liyanagunawardena, T. R., Adams, A. A., \& Williams, S. A. (2013). MOOCs: A systematic study of the published literature 2008-2012. The International Review of Research in Open and Distributed Learning, 14(3), 202-227.

López-Meneses, E. J., Bernal, C., Leiva, \& J. J., Martín, A. H. (2018). Validación del instrumento didáctico de valoración de observatorios digitales sobre MOOC: CUVOMOOC mediante el método Delphi. Campus Virtuales, 7(1), 95-110. 
Margaryan, A., Blanco, M., and Littlejohn, A. (2015). Instructional quality of massive open online courses (MOOCs). Computers \& Education, 80, 77-83.

McLaren, J., Donaldson, J., \& Smith, S. (2018). Learning analytics suggest a positive experience: A descriptive analysis of a care and compassion MOOC (Massive Open Online Course). University of Stirling and Edinburgh Napier University, Scotland, UK.

https://www.researchgate.net/profile/Julie_Mclaren2/publication/329674115_ Learning_Analytics_Suggest_a_Positive_Experience/links/5c14e153a6fdcc494ff5b1 49/Learning-Analytics-Suggest-a-Positive-Experience.pdf

Machin, D., \& Mayr, A. (2012) Presenting speech and speakers: Quoting verbs. In D. Machin \& A. Mayr (Eds). How to do critical discourse analysis: A multimodal introduction (pp. 57-76). London: Sage Publications Ltd (Chapter 3).

MacLachlan, G., \& Reid, I. (1994). Framing and interpretation. Melbourne, Australia, Melbourne University Press.

Magen-Nagar, N. (2017). Learning strategies as a mediator for motivation and a sense of achievement among students who study in MOOCs. Education and Information Technologies, 22(3), 1271-1290.

Mak, H. C. (2017). Harnessing MOOCs for the practice of science (Editorial). Cell Systems, 5(3), 157.

Méchoulan, E. \& Carr, A. (2015). Intermediality: An introduction to the arts of transmission. SubStance, 44(3), 3-18.

Meinert, E. Alturkistani, A., Brindley, D., Carter, A., Wells, G., \& Car, J. (2018). Protocol for a mixed-methods evaluation of a massive open online course on real world evidence. BMJ Open, 8, e25188, doi:10.1136/bmjopen-2018-025188.

Méndez García, C. M. (2013). Design and implementation of Massive Online Open Courses (MOOCs): Expectations and practical recommendations. RED Revista de Educación a Distancia, 39, 1-19.

Milheim, W. D. (2014). Massive open online courses (MOOCs): Current applications and future potential. Educational Technology, 53(3), 38-42.

Millward, W. T. (2019, April 29). More MOOC madness? UK’s FutureLearn raises \$65M to expand global footprint. EdSurge, Retrieved May 5, 2019, from https://www.edsurge.com/news/2019-04-29-more-mooc-madness-uk-s-futurelearnraises-65m-to-expand-global-footprint 
Mondal, B. (2017). The impact of new information and communication technology (ICT) module as learning tool in higher education. International Journal of Scientific Research in Computer Science, Engineering and Information Technology, 2(5), 797 801.

Moody, J. (2018, Oct. 14). How MOOC-based master's degrees may transform higher ed. $\begin{array}{llll}\text { Forbes, } & \text { Retrieved } & \text { May } & 4\end{array}$ from https://www.forbes.com/sites/joshmoody/2018/10/14/how-mooc-based-mastersdegrees-may-transform-higher-ed/\#375f86144efc

Murray, S. (2019, March 4). Moocs struggle to lift rock-bottom completion rates. Financial Times, Retrieved from https://www.ft.com/content/60e90be2-1a77-11e9-b191$175523 \mathrm{~b} 59 \mathrm{~d} 1 \mathrm{~d}$

Nesselhauf, J., \& Schleich, M. (2015). A stream of medial consciousness. Transmedia storytelling in contemporary German quality television. Image, Special Issue, Media Convergence and Transmedial Worlds, 50-62.

Nortvig, A.-M., \& Christiansen, R. B. (2017). Institutional collaboration on MOOCs in education-A literature review. International Review of Research in Open and Distance Learning, 18(6), 306-316.

O’Prey, P. (2013). Massive open online course: Higher education, digital moments? Retrieved May 6, 2019 from https://www.universitiesuk.ac.uk.

Paldy, L. G. (2013). Guest editorial: MOOCs in your future. Journal of College Science Teaching, 42(4), 6-7.

Pappano, L. (2012, Nov. 2). The year of the MOOC. The New York Times, Retrieved May 10, 2012, from

https://www.nytimes.com/2012/11/04/education/edlife/massive-open-online-

courses-are-multiplying-at-a-rapid-pace.html

Perna, L., Ruby, A., Boruch, R. F., Wang, N., Scull, J., Ahmad, S., \& Evans, C. (2014). Moving through MOOCs: Understanding the progression of users in massive open online courses. Educational Researcher, 43(9), 421-432.

Petronzi, D., \& Hadi, M. (2016). Exploring the factors associated with MOOC engagement, retention, and the wider benefits for learners. European Journal of Open, Distance and e-Learning, 19(2), 129-146.

Quendler, E., \& Lamb, M. (2016). Learning as a lifelong process - Meeting the challenges of the changing employability landscape: Competences, skills and knowledge for 
sustainable development. International Journal of Continuing Engineering Education and Lifelong Learning, 26(3), 273-293.

Reeves, T. C., \& Hedberg, J. G. (2014). MOOCs: Let's get real. Educational Technology, 54(1), 3-8.

Reich, J., \& Ruipérez-Valiente, J. A. (2019). The MOOC pivot. Science, 363(6423), 130-131. Reilly, E. D., Williams, K. M., Stafford, R. E., Corliss, S. B., Walkow, J. C., \& Kidwell, D. K. (2016). Global times call for global measures: Investigating automated essay scoring in linguistically-diverse MOOCs. Journal of Interactive Online Learning, 20(2), 1-13.

Rogers, R., Malancharuvil-Berkes, E., Mosley, M., Hui, D., \& Joseph, G. (2005). Critical discourse analysis in education. Review of Educational Research, 75(3), 365- 416.

Rogers, R. (2017). Critical discourse analysis in education. In S. Wortham, D. Kim, \& S. May (Eds). Discourse and Education (pp. 41-54). Encyclopedia of Language and Education book series ( $3^{\text {rd }}$ edition). Springer, Cham https://doi.org/10.1007/978-3319-02243-7_3.

Rohs, M., \& Ganz, M. (2015). MOOCs and the claim of education for all: A disillusion by empirical data. International Review of Research in Open and Distributed Learning, 16(6), 1-19.

Schauffhauser, D. (2019, March, 20). How MOOCs make money. Campus Technology, Retrieved May 5, 2019 from

https://campustechnology.com/articles/2019/03/20/how-moocs-make-money.aspx

Schiffrin, D., Tannen, D., \& Hamilton, H. E. (Eds). (2003). The handbook of discourse analysis. Malden, MA: Wiley-Blackwell.

Schophuizen, M., Kreijns, K., Stoyanov, S., \& Kalz, M. (2018). Eliciting the challenges and opportunities organizations face when delivering open online education: A groupconcept mapping study. The Internet and Higher Education, 36, 1-12.

Schrag, P. G. (2014). MOOCs and legal education: Valuable innovation or looming disaster? Villanova Law Review, 59, 83-134.

Scolari, C. A. (2015). From (new)media to (hyper)mediations. Recovering Jesús Martín Barbero's mediation theory in the age of digital communication and cultural convergence. Information, Communication \& Society, 18(9): 1092-1107. doi: 10.1080/1369118X.2015.1018299.

Selingo, J. J. (2014a). MOOC U: Who is getting the most out of online education and why. Simon \& Schuster. 
Selingo, J. J. (2014b, Oct. 19). Demystifying the MOOC. The New York Times, Retrieved May 10,2019 from https://www.nytimes.com/2014/11/02/education/edlife/demystifying-themooc.html?ref=bits

Shah, D. (2016, Dec. 29). Monetization over massiveness: Breaking down MOOCs by the numbers in 2016. EdSurge, https://www.edsurge.com/news/2016-12-29-monetizationover-massiveness-breaking-down-moocs-by-the-numbers-in-2016

Shah, D. (2018, Dec.11). By the numbers: MOOCs in 2018. Class Central MOOC Report, Retrieved May 17, 2019 from https://www.classcentral.com/report/mooc-stats-2018/

Shapiro, H. B., Lee, C. H., Wyman Roth, N. E., Li, K., Çetinkaya-Rundel, M., \& Canelas, D. A. (2017). Understanding the massive open online course (MOOC) student experience: An examination of attitudes, motivations, and barriers. Computers \& Education, 110, $35-50$.

Sharif, A., \& Magrill, B. (2015). Discussion forums in MOOCs. International Journal of Learning, Teaching and Educational Research, 12(1), 119-132.

Signorelli, P., \& Hovious, A. (2014). MOOCs. American Libraries, 45(5), 34-35.

Sloep, P. B., \& Schuwer, R. (2016). Of two contrasting philosophies that underpin openness in education and what that entails. In M. Deimann \& M. A. Peters (Eds.), The philosophy and theory of open education (pp. 83-100). New York: Peter Lang Publishing.

Slomanson, W. R. (2014). Blended learning: A flipped classroom experiment. Journal of Legal Education, 64(1), 93-102.

Steffens, K. (2015). Competences, learning theories and MOOCs: Recent developments in lifelong learning. European Journal of Education, 50(1), 41-59.

Stephens, M., \& Jones, K. M. L. (2014). MOOCs as LIS professional development platforms: Evaluating and refining SJSU's first not-for-credit MOOC. Journal of Education for Library and Information Science, 55(4), 345-361.

Stewart, B. (2013). Massiveness + openness = new literacies of participation? MERLOT Journal of Online Learning and Teaching, 9(2), 228-238.

Swinnerton, B. J., Hotchkiss, S., \& Morris, N. P. (2017). Comments in MOOCs: Who is doing the talking and does it help? Journal of Computer Assisted Learning, 33(1), 51-64.

Terras, M. M., \& Ramsay, J. (2015). Massive open online couses (MOOCs): Insights and challenges from a psychological perspective. British Journal of Educational Technology, 46(3), 472-487. 
Trentin, G., \& Bocconi, S. (2014). The effectiveness of hybrid solutions in higher education: Call for hybrid-teaching instructional design. Educational Technology, 54(5), 12-21.

Tseng, S.-F., Tsao, Y.-W., Yu, L.-C., Chan, C.-L., \& Lai, K. R. (2016). Who will pass? Analyzing learner behaviors in MOOCs. Research and Practice in Technology Enhanced Learning, 11(8), doi: 10.1186/s41039-016-0033-5.

van de Oudeweetering, K., \& Agirdag, O. (2018). MOOCs as accelerators of social mobility? A systematic review. Journal of Educational Technology \& Society, 21(1), 1-11.

Van Dijk, T. A. (2014). Discourse-cognition-society. In C. Hart \& P. Cap (Eds). Contemporary studies in critical discourse analysis (pp. 121-146), London, Bloomsbury.

Van Dijk, T. A. (2016). Análisis critico del discurso. Revista Austral de Ciencias Sociales, 30, 203-222.

Van Leeuwen, T. (2015). Critical discourse analysis. The International Encyclopedia of Language and Social Interaction, Retrieved May 4, 2019 from https://doi.org/10.1002/9781118611463.wbielsi174.

Vázquez Cano, E., \& López Meneses, E. (2014). Los MOOC y la educación superior: la expansión del conocimiento. Profesorado. Revista de Currículum y Formación de Profesorado, 18(1), 3-12.

Veletsianos, G., \& Shepherdson, P. (2016). A systematic analysis and synthesis of the empirical MOOC literature published in 2013-2015. The International Review of Research in Open and Distributed Learning, 17(2), 198-221.

Vitiello, M., Walk, S., Helic, D., Chang, V., \& Gütl, C. (2018). User behavioral patterns and early dropouts detection: Improved users profiling through analysis of successive offering of MOOC. Journal of Universal Computer Science, 24(8), 1131-1150.

Volles, N. (2014). Lifelong learning in the EU: Changing conceptualisations, actors, and policies. Studies in Higher Education, 1-21.

Walji, S., Deacon, A., Small, J., \& Czerniewicz, L. (2016). Learning through engagement: MOOCs as an emergent form of provision. Distance Education, http://dx.doi.org/10.1080/01587919.2016.1184400.

Wang, Y., \& Baker, R. (2015). Content or platform: Why do students complete MOOCs? MERLOT Journal of Online Learning and Teaching, 11(1), 1-18.

Wang, Y., \& Baker, R. (2018). Grit and intention: Why do learners complete MOOCs? International Review of Research in Open and Distributed Learning, 19(3), 20-42. 
Watted, A., \& Barak, M. (2018). Motivating factors of MOOC completers: Comparing between university-affiliated students and general participants. The Internet and Higher Education, 37, 11-20.

Weller, M. (2015). MOOCs and the Silicon Valley narrative. Journal of Interactive Media in Education, 1, 1-7.

Williams, K. M., Stafford, R. E., Corliss, S. B., \& Reilly, E. D. (2018). Examining student characteristics, goals, and engagement in massive open online courses. Computers \& Education, 126, 433-442.

Woods, N. (2006). Describing discourse: A practical guide to discourse analysis. London, UK, Hodder Arnold, Hachette.

Wrigley, C., Mosely, G., \& Tomitsh, M. (2018). Design thinking education: A comparison of massive open online courses. she ji The Journal of Design, Economics, and Innovation, 4(3), 275-292.

Xiong, Y., Li, H., Kornhaber, M. L., Suen, H. K., Pursel, B., \& Goins, D. D. (2015). Examining the relations among student motivation, engagement, and retention in a MOOC: A structural equation modeling approach. Global Education Review, 2(3), 23-33.

$\mathrm{Xu}$, B., \& Yang, D. (2016). Motivation classification and grade prediction for MOOCs learners. Computational Intelligence and Neuroscience, 1-7

http://dx.doi.org/10.1155/2016/2174613.

Ye, C., \& Biswas, G. (2014). Early prediction of student dropout and performance in MOOCs using higher granularity temporal information. Journal of Learning Analytics, 1(3), 169172.

Young, J. R. (2018, Aug. 21). MOOCs are no longer massive. And they serve different audiences than first imagined. EdSurge, Retrieved May 4, 2019 from https://www.edsurge.com/news/2018-08-21-moocs-are-no-longer-massive-and-theyserve-different-audiences-than-first-imagined

Yousef, A. M. F., Chatti, M. A., Schroeder, U., \& Wosnitza, M. (2014). What drives a successful MOOC? An empirical examination of critera to assure design quality of MOOCs. In Proceedings of the 2014 IEEE 14th International Conference on Advanced Learning Technologies, Athens, Greece.

Zhang, Q., Cesar Bonafini, F., Lockee, B. B., Jablokow, K. W., \& Hu, X. (2019). Exploring demographics and students' motivation as predictors of completion of a masive open online course. International Review of Research in Open and Distributed Learning, 20(2), 140-161. 
Zhong, S.-H., Zhang, Q.-B., Li, Z.-P., \& Liu, Y. (2016). Motivations and challenges in MOOCs with Eastern insights. International Journal of Information and Education Technology, 6(12), 954-960.

Zhou, M. (2016). Chinese university students' acceptance of MOOCs: A self-determination perspective. Computers \& Education, 92-93, 194-203.

Zhu, M., Sari, A., \& Lee, M. M. (2018). A systematic review of research methods and topics of the empirical MOOC literature. The Internet and Higher Education, 37, 31-39.

Zion Market Research. (2019, March 14). Massive open online course market by component (platform and services), by course (humanities, computer science and programming, business management, science, health and medicine, education and training, engineering, and others), and by user type (high school, undergraduate, postgraduate, and corporate) Global Industry Perspective, Comprehensive Analysis, and Forecast, 2018-2025. Retrieved May 5, 2019 from

https://www.globenewswire.com/news-elease/2019/03/14/1752909/0/en/Global-

Massive-Open-Online-Course-Market-Will-Reach-USD-25-33-Billion-By-2025-ZionMarket-Research.html 